\title{
Peningkatan ketrampilan pemuda di sekitar Masjid Ash-Siddiq, Umbansari Rumbai Pekanbaru melalui kegiatan pelatihan berbasis teknologi
}

\author{
Mochamad Susantok ${ }^{\oplus}$, \& Sugeng Purwantoro Edy GS \\ Politeknik Caltex Riau \\ *santok@pcr.ac.id
}

\begin{abstract}
Abstrak. Direktorat kepemudaan dan olahraga Yayasan Islam Ash-Siddiq (YIAS) berada di kompleks masjid AshSiddiq sebagai pusat kegiatan keislaman masyarakat muslim di 3 RW 10,11, dan 13 di kelurahan Umbansari kecamatan Rumbai Kota Pekanbaru. Permasalahannya adalah kurangnya SDM terlatih untuk kegiatan publikasi dan minimnya kegiatan remaja masjid. Tujuan program adalah meningkatkan partisipasi pemuda lingkungan dalam kegiatan-kegiatan positif juga termasuk meningkatnya jumlah jama'ah sholat 5 waktu dari kalangan pemuda sebagai upaya pembinaan dan koordinasi kegiatan pada Direktorat kepemudaan dan olahraga YIAS. Metode pelaksanaan kegiatan program meliputi penyediaan layanan internet di lingkungan masjid Ash-Siddiq sebagai sarana publikasi kegiatan melalui media sosial. Kemudian selain itu kegiatan workshop video editing dan pelatihan dasar panahan sebagai pembekalan skill teknis untuk mendukung program publikasi kegiatan YIAS. Hasil program berupa dampak meningkatnya peran serta pemuda dalam kegiatan keagamaan seperti sholat berjama'ah di masjid yang terjadi peningkatan rata-rata $174.4 \%$. Selain itu peningkatan publikasi di media sosial facebook, instagram, dan youtube menjadi rata-rata 9.6 postingan untuk setiap akun official YIAS di media sosial. Kemudian hasil dari analisa survey usability terhadap penggunaan layanan internet dan penggunaan peralatan video streaming untuk melakukan publikasi secara langsung, maka didapatkan hasilnya yaitu $90.9 \%$ atau senilai 4.54 dalam skala $1-5$.
\end{abstract}

Kata kunci: pemuda masjid, video editing, panahan

\begin{abstract}
The Directorate of Youth and Sports of the Ash-Siddiq Islamic Foundation (YIAS) is located at the AshSiddiq mosque complex as a center for Islamic activities for the Muslim community in 3 RW 10, 11 and 13 in Umbansari sub-district, Rumbai district, Pekanbaru City. The problem is the lack of trained human resources for publication activities and the lack of youth activities in mosques. The aim of the program is to increase the participation of environmental youth in positive activities as well as to increase the number of congregations praying 5 times a day among youth as an effort to foster and coordinate activities at the YIAS Youth and Sports Directorate. The method of implementing program activities includes the provision of internet services within the Ash-Siddiq mosque as a means of publicizing activities through social media. Then in addition to video editing workshops as technical skills provision to support the YIAS activity publication program. The program results in the form of the impact of increasing youth participation in religious activities such as congregational prayer in mosques which increased by an average of $174.4 \%$. In addition, the increase in publications on social media Facebook, Instagram, and YouTube to an average of 9.6 posts for each YIAS official account on social media. Then the results of the usability survey analysis of the use of internet services and the use of video streaming equipment to publish directly, the results are $90.9 \%$ or 4.54 on a scale of 1-5.
\end{abstract}

Keywords: youth mosque, editing video and archery

To cite this article: Susantok, M., \& S. P. Edy GS. 2020. Peningkatan ketrampilan pemuda di sekitar Masjid AshSiddiq, Umbansari Rumbai Pekanbaru melalui kegiatan pelatihan berbasis teknologi. Unri Conference Series: Community Engagement 2: 44-49. https://doi.org/10.31258/unricsce.2.44-49

(C) 2020 Authors

Peer-review under responsibility of the organizing committee of Seminar Nasional Pemberdayaan Masyarakat 2020 


\section{PENDAHULUAN}

Masjid merupakan tempat ibadah kaum muslimin atau umat islam, seiring semakin meningkatnya pemahaman kaum muslimin tentang agama islam, fungsi masjid bertambah menjadi pusat kegiatan keagaman. Kegiatan di Masjid jadi beragam selain sholat 5 waktu, kegiatan pengajian rutin, kegiatan peringatan hari besar Islam, dan bahkan kegiatan pendidikan islam seperti ma'had dan MDA (Madrasah Diniyah Awaliyah) (Muna 2019).

Masjid Ash-Siddiq adalah masjid yang terletak di kelurahan Umbansari Kecamatan Rumbai Kota Pekanbaru. Masjid Ash-Siddiq dibawah naungan Yayasan Islam Ash-Siddiq (YIAS) yang memiliki Direktorat Kepemudaan dan Olahraga memiliki beberapa kegiatan rutin dan insidentil yang cukup banyak selain sholat berjama'ah 5 waktu. Dalam sepekan ada 3 kali kegiatan kajian keislaman rutin, dan kegiatan pendidikan seperti MDA, serta kegiatan PHBI setiap hari-hari besar keislaman.

YIAS berada di wilayah yang cukup strategis yaitu di sekitar 3 RW meliputi RW 10, 11, dan 13 dengan total kurang lebih $\pm 1100 \mathrm{KK}$. Potensi ini sangat mendukung untuk peran dan fungsi masjid sebagai penebar kebaikan melalui manfaat berbagai kegiatan yang dilakukan. Di sisi lain jumlah pemuda dengan rentang usia 13-18 th disekitar lingkungan YIAS dan Masjid Ash-Siddiq berjumlah \pm 50 orang yang masih belum dioptimalkan. Beberapa peran seperti tim publikasi dan pendukung teknis kegiatan yang bisa dilakukan oleh remaja masjid, belum optimal disebabkan jumlah remaja masjid yang aktif sekitar 3-5 orang.

Dua isu penting ini diangkat dalam program Pengabdian Masyarakat ini yaitu optimalisasi peran pemuda dalam kegiatan di masjid dan kedua teknik publikasi kegiatan islam di lingkungan YIAS melalui internet (Hasugian J. 2005). Tujuan kegiatan ini agar kegiatan masjid Ash-Siddiq terpublikasi melalui media sosial (Cahyono A. S. 2016) di internet yang dilakukan melalui peran pemuda dan remaja masjid sebagai tim media untuk melakukan editing video dan broadcasting.

\section{MASALAH}

Direktorat Kepemudaan dan Olah raga sebagai mitra memiliki permasalahan dalam hal pendayagunaan potensi pemuda lingkungan dan remaja masjid Ash-Siddiq. Pemuda lingkungan lebih banyak aktifitas pribadi dan kelompok (geng) yang belum diarahkan ke hal yang positif sehingga berdampak kepada kegiatan yang sia-sia dan bahkan berpotensi meresahkan masyarakat. Beberapa diantara permasalahan yang teridentifikasi adalah sebagai berikut:

a) Setiap malam minggu, pemuda lingkungan berkumpul untuk nongkrong di warung dan bermain game online sampai waktu dini hari. Dalam hal ini banyak waktu yang terbuang karena kegiatan yang tidak bermanfaat.

b) Terjadinya peristiwa berupa kemalingan dirumah penduduk sekitar RW dan masjid Ash-Siddiq yang terkadang dilakukan oleh beberapa pemuda sekitar. Walaupun belum terbukti secara hukum, namun prasangka warga sangat kuat dilakukan oleh oknum remaja sekitar. Dalam kasus ini, peran pemuda lingkungan juga bisa sebagai tim keamanan lingkungan dengan melalui ronda dan pengawasan setiap saat melalui kegiatan-kegiatan rutin oleh pemuda lingkungan.

c) Minimnya peran serta pemuda lingkungan dalam aktifitas warga dan jama'ah masjid Ash-Siddiq.

d) Hanya 3-5 orang pemuda lingkungan yang menjadi jama'ah tetap sholat lima waktu di masjid Ash-Siddiq

e) Belum ada dibentuk kepengurusan remaja masjid Ash-Siddiq.

f) Keterbatasan paket internet beberapa warga untuk mendukung pembelajaran daring di masa pandemi covid19. Hal ini menjadi permasalahan baru bagi para pemuda yang juga sedang masa aktif belajar secara daring. Saat ini mitra yaitu direktorat kepemudaan dan olahraga YIAS telah memiliki sarana yang memadai berupa masjid ash-Siddiq yang nyaman, lapangan masjid yang luas dan bisa juga untuk berbagai kegiatan olahraga outdoor, serta ruang kelas yang memadai untuk kegiatan pelatihan ketrampilan. Namun fasilitas tersebut masih belum dioptimalkan untuk pendayagunaan potensi pemuda lingkungan dan remaja masjid, sehingga perlu diberikan fasilitas pendukung dan teknologi yaitu berupa diantaranya

- Fasilitas akses internet gratis di area masjid dengan manajemen akses dan monitoring. Selain fasilitas yang diberikan, edukasi kepada pemuda juga sangat penting untuk memindahkan tempat nongkrong yang sebelumnya di warung menjadi di masjid dengan akses informasi yang bermanfaat. Fasilitas ini diharapkan menjadi solusi bagi permasalahan a, d, e dan f yaitu dengan meningkatkan frekuensi aktifitas mereka di masjid.

- Fasilitas pelatihan dan workshop video editing. Masjid Ash-Siddiq saat ini memerlukan SDM penyedia konten digital berupa video dan infografis untuk setiap kegiatan keislaman yang kemudian akan ditampilkan dalam media informasi digital dan internet. YIAS juga telah memiliki akun media sosial berupa 
channel broadcast, namun dari sisi konten yang sangat minim disebabkan kekurangan SDM. Fasilitas ini diharapkan menjadi solusi bagi permasalahan $\mathrm{c}$ dan e dalam hal meningkatkan peranan pemuda dalam kegiatan masjid Ash-Siddiq.

\section{METODE PENERAPAN}

Permasalahan yang diungkap pada bagian sebelumnya memerlukan solusi yang tepat untuk dapat diimplementasikan pada lingkungan Direktorat Kepemudaan dan Olahraga YIAS. Metode penyelesaian beberapa masalah tersebut berupa penyediaan infrastruktur dan peningkatan SDM yang akan diuraikan sebagai berikut:

\section{Penyediaan infrastruktur internet}

Membangun infrastruktur akses internet dan WiFi di lingkungan masjid Ash-Siddiq untuk mendukung publikasi kegiatan-kegiatan di masjid ke internet melalui media sosial seperti facebook, youtube, dan instagram. Gambar 1 menunjukkan desain hotspot internet di lingkungan Masjid Ash-Siddiq, dengan desain tersebut semua area lingkungan masjid terjangkau akses internet.

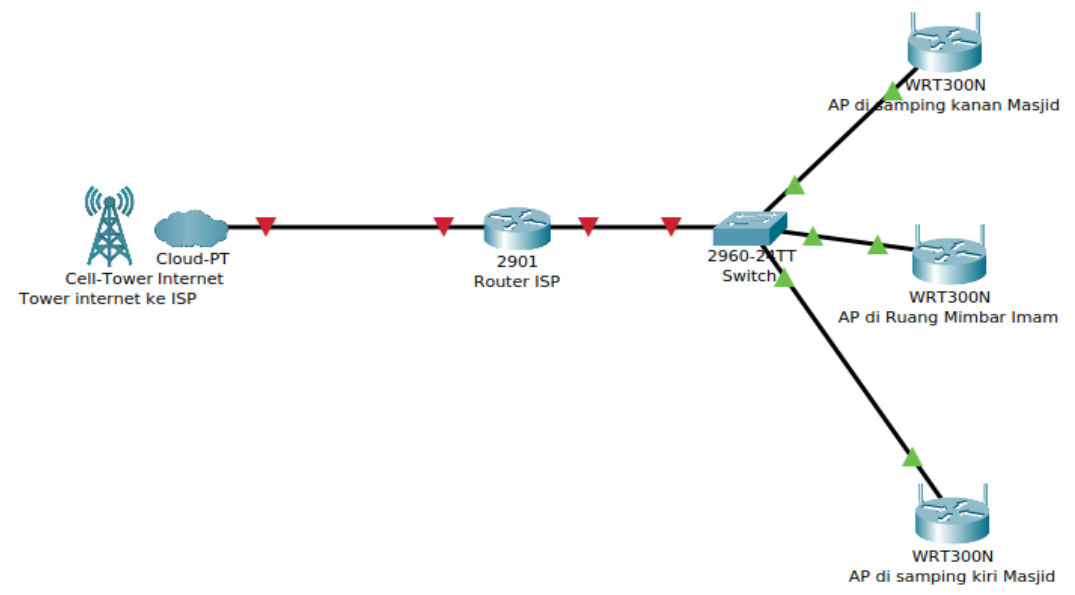

Gambar 1. Desain Hotspot WiFi Internet Masjid Ash-Siddiq

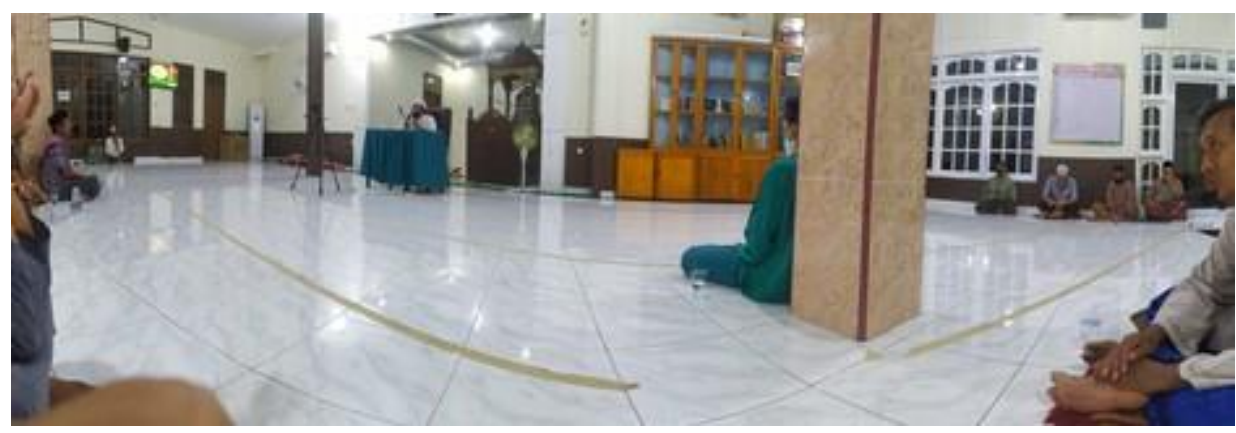

Gambar 2. Siaran langsung meliput kegiatan kajian rutin pekanan

Selain untuk meliput kegiatan dan publikasi kegiatan rutin seperti gambar 2 diatas, penyediaan akses internet juga dimanfaatkan oleh remaja dan pemuda masjid serta anak-anak usia belajar untuk mendukung pembelajaran secara daring bagi yang terkendala paket internet. Selain itu sebagai sarana mencari informasi untuk pembelajaran dan informasi penting lainnnya bagi jama'ah untuk media belajar (SetyaWatie E. D. 2016). Sedangkan fairness diberikan dengan memberlakukan aturan login dan jam akses melalui perangkat wireless router. 


\section{Kegiatan workshop video editing dan broadcasting}

Metode yang kedua yaitu dengan memberikan kemampuan dan ketrampilan kepada remaja dan pemuda berupa workshop video editing dan broadcasting. Kemampuan untuk membuat video, teknik pengambilan gambar dan kemampuan menggunakan perangkat lunak aplikasi video editing seperti flimora. Kegiatan ini diharapkan mampu memberikan kontribusi berupa tersedianya SDM untuk memproduksi video yang layak untuk dinikmati oleh publik di internet. Selain itu kemampuan untuk mengelola media sosial sebagai wadah publikasi di internet juga diberikan sebagai dasar digital marketing.

Dua metode ini saling terkait untuk menjaga eksistensi syi'ar kegiatan keislaman ke dunia maya internet. Serta memberikan kesempatan berkarya bagi pemuda melalui kemampuan produksi video untuk publikasi (syi'ar) dalam rangka optimalisasi peran pemuda di sekitar lingkungan YIAS. Dampaknya bagi masyarakat adalah mudahnya mengakses informasi dan layanan kegiatan keislaman melalui media sosial masjid.

\section{HASIL DAN KETERCAPAIAN SASARAN}

Pembuatan layanan akses jaringan internet dengan konfigurasi seperti pada Gambar 1, menghasilkan status koneksi seperti pada Gambar 3 berikut. Menggunakan teknik captive portal membuat user/pengguna melakukan autentikasi terlebih dahulu sebelum diberikan akses internet oleh router.

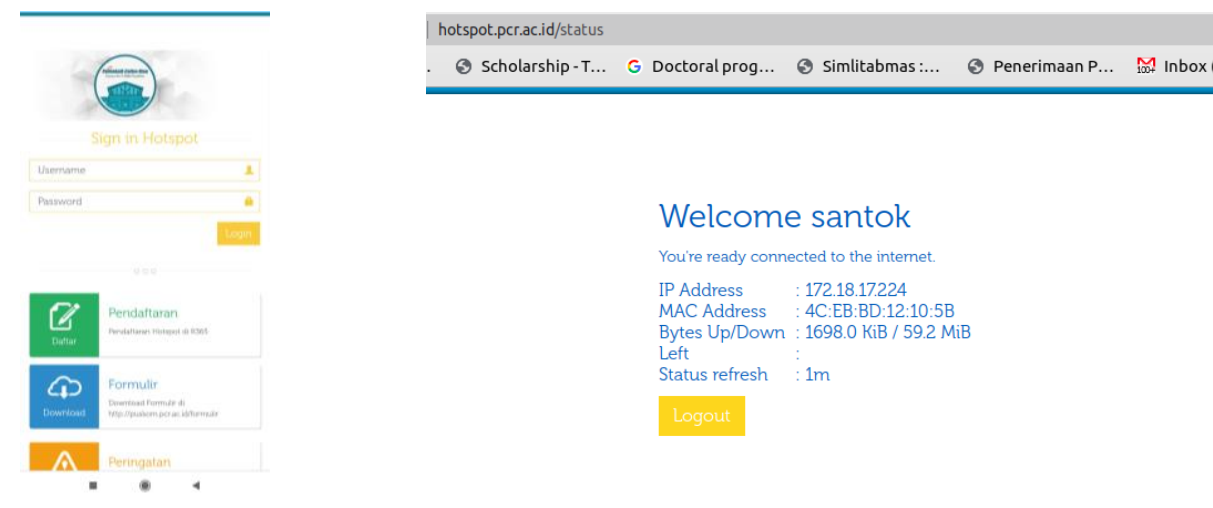

Gambar 3. Halaman login dan status koneksi

Penyediaan layanan internet di area masjid Ash-Siddiq memberikan dampak terhadap tingkat kunjungan masyarakat khususnya pemuda dan remaja ke masjid untuk beribadah, bermain dan belajar. Hal ini ditunjukkan dengan terjadinya peningkatan jumlah jama'ah sholat lima waktu usia remaja di masjid Ash-Siddiq dalam masa new normal sekitar $174.4 \%$ berikut tabel jumlah jama'ah sholat lima waktu di kalangan remaja dengan usia 13-18 tahun sebelum dan sesudah program PkM. Pengambilan datanya melalui pengamatan selama 1 pekan dan diambil angka rata-rata untuk setiap waktu sholatnya.

Tabel 1. Peningkatan jumlah jama'ah sholat lima waktu usia remaja

\begin{tabular}{lccc}
\hline $\begin{array}{c}\text { Sholat 5 } \\
\text { waktu }\end{array}$ & $\begin{array}{c}\text { Sebelum Program PKM } \\
\text { (Jan-April 2020) }\end{array}$ & $\begin{array}{c}\text { Setelah Program PKM } \\
\text { (Mei-September 2020) }\end{array}$ & Peningkatan (\%) \\
\hline Subuh & 1.9 & 3.4 & 84.6 \\
Dzuhur & 1.4 & 4.3 & 203 \\
Ashar & 1.3 & 4 & 211 \\
Maghrib & 3.1 & 8 & 154.6 \\
Isya' & 1.6 & 5 & 218.2 \\
Rata-rata & 1,9 & 4.9 & 174.4 \\
\hline
\end{tabular}

Selain dari segi jumlah jama'ah sholat 5 waktu, aktifitas publikasi kegiatan masjid Ash-Siddiq di media sosial juga meningkat seperti Tabel 2 berikut 
Tabel 2. Aktifitas media sosial akun offical masjid Ash-Siddiq dan YIAS

\begin{tabular}{lcc}
\hline Media Sosial & $\begin{array}{c}\text { Aktifitas Sebelum Program PKM (Jan- } \\
\text { April 2020) }\end{array}$ & $\begin{array}{c}\text { Aktifitas Setelah Program PKM (Mei- } \\
\text { September 2020) }\end{array}$ \\
\hline Yotube & 0 & 2 \\
Facebook & 0 & 24 \\
Instagram & 0 & 3 \\
\hline
\end{tabular}

Youtube : https://www.youtube.com/channel/UC96qXjqZBh9clizImh99Z3w/

Facebook : https://www.facebook.com/Ash-Shiddiq_Official-303679810532776

https://www.facebook.com/masjid.a.rumbai

Instagram : https://www.instagram.com/p/CFQdawMnKWV/?igshid=jpmq30wqa2x

Selain itu untuk melihat tingkat kebergunaan (usability) (Nurhadryani 2003) penyediaan layanan internet yaitu pada hasil kuesioner yang telah dibagikan mendapatkan hasil sebagai berikut:

Tabel 3. Data hasil survey usability

\section{A. Usefulness}

A.1 Layanan ini sangat bermanfaat untuk mengetahui informasi kegiatan masjid setiap harinya

A.2 Saya selalu menggunakan layanan ini setiap kali berkunjung ke masjid

A.3 Saya sering melihat akun medsos official YIAS dan masjid-Ash-Siddiq untuk mengetahui informasi kegiatan di masjid

A.4 Informasi yang disampaikan dalam layanan ini sudah sangat sesuai dengan kebutuhan saya

\section{B. Ease of Use}

B.1 Saya mengetahui informasi cara menggunakan layanan internet di masjid

B.2 Saya merasa mudah untuk mencari informasi menggunakan akses internet di masjid

B.3 Saya tidak merasa kesulitan dalam mengakses internet di masjid

B.4 Saya dapat mencari informasi dengan mudah menggunakan layanan internet di masjid

B.5 Saya tidak melihat adanya ketidakkonsistenan selama saya menggunakan layanan ini

\section{Satisfaction}

C.1 Saya merasa puas dengan layanan internet di masjid

C.2 Saya akan merekomendasikan layanan internet ini ke tetangga

C.3 Layanan akses internet ini bekerja seperti yang saya inginkan

C.4 Layanan ini menarik

C.5 Saya memberi nilai 5 (skala 1-5) untuk layanan akses internet ini. 
- Efisien (usefulnes), 93.5\% atau senilai 4.67 menyatakan bahwa layanan internet sangat berguna dan efisien.

- Efektifitas (ease of use), $91.6 \%$ atau senilai 4.58 menyatakan bahwa layanan internet sangat mudah dalam menggunakannya.

- Kepuasan (statisfaction), $87.6 \%$ atau senilai 4.38 menyatakan puas dengan layanan ini yang menunjukkan masih ada ruang improvement untuk mengembangkan fitur layanan ini menjadi lebih baik.

Pembuatan konten video kegiatan menggunakan peralatan video editing bisa terwujud dan didukung dengan keberadaan sarana media publikasi melalui layanan internet di masjid. Kedua fitur ini menjadikan Direktorat kepemudaan dan olahraga mampu mengoptimalkan peran pemuda untuk salah satunya melakukan publikasi kegiatan secara langsung atau live streaming di akun official media sosial YIAS dan masjid AshSiddiq.

\section{KESIMPULAN}

Keberadaan fitur baru di lingkungan YIAS dan Masjid Ash-Siddiq berupa layanan akses internet dan peralatan video streaming sangat disambut baik oleh pengurus, jama'ah dan masyarakat disekitar. Hal ini ditunjukkan dengan angka rata-rata prosentase usability yang sangat tinggi yaitu $90.9 \%$ atau senilai 4.54 dalam skala 1-5.

Sedangkan untuk nilai efektifitas di media sosial meningkat $100 \%$ dari yang belum ada menjadi ada aktifitas. Eksistensi informasi di media sosial menjadi penting saat ini dimasa pandemi dimana sebagian jama'ah dan masyarakat tetap bersosialisi melalui media online. Peran remaja masjid dan pemuda lingkungan sebagai penggiat media sosial sangat dibutuhkan sebagai upaya menjaga pelayanan YIAS dan Masjid ditengah masa pandemi saat ini.

\section{UCAPAN TERIMA KASIH}

Ucapan terima kasih kepada pemberi/sumber dana yaitu Kemenristekdikti dan Institusi penulis Politeknik Caltex Riau yang mendukung penuh program ini sampai mendapatkan hasil yang diharapkan. Kemudian juga terima kasih kepada Mitra atas kerjasamanya dan semoga bermanfaat bagi jama'ah dan masyarakat di sekitar lingkungan YIAS khususnya di kelurahan Umbansari RW 10,11, dan 13 Kecamatan Rumbai.

\section{DAFTAR PUSTAKA}

Muna D. dkk. 2019. Pemberdayaan Masyarakat melalui Optimalisasi Fungsi Masjid sebagai Pusat Kegiatan Kemasyarakatan di Dusun Sawahan. Dalam Prosiding Konferensi Pengabdian Masyarakat, 1, 285-287.

Hasugian J. 2005. Pemanfaatan Internet, Studi Kasus Tentang Pola, Manfaat dan Tujuan Penggunaan Internet oleh Mahasiswa. Jurnal Studi Perpusatakaan dan Informasi, 1(1).

SetyaWatie E. D. 2011. Komunikasi dan Media Sosial. Jurnal The Messenger, 3(1), 69-74.

Nurhadryani, Y., Sianturi, S. K., Hermadi, I., \& Khotimah, H. 2003. Pengujian Usability untuk Meningkatkan Antarmuka Aplikasi Mobile. Jurnal Ilmu Komputer dan Agri-Informatika, 2(2), 83-93.

Cahyono A. S. 2016. Pengaruh Media Sosial Terhadap Perubahan Sosial Masyarakat di Indonesia. Jurnal Ilmu Sosial dan Politik FISIP Universitas Tulungagung 